\title{
Development Learning Tool Modification of Music and Dance to Increase Physical Development in Early Childhood on the Cluster Jempiring Denpasar
}

\author{
MG. Rini Kristiantari, I Gusti Agung Oka Negara
}

Universitas Pendidikan Ganesha, Singaraja Bali, Indonesia

e-mail: rinibali@yahoo.co.id

\begin{abstract}
This study aims to develop and produce products that Irish Music and Dance Learning Modifications to Increase Physical Development in Early Childhood Motor on the Jempiring Denpasar Cluster Academic Year 2015-2016. The approach used in this study is a research and development for the main purpose of this study was to develop a product such as a learning tool game modification of music and dance that is adaptable and effective in accordance with the conditions and the real needs on the ground (Borg \& Gall, 1989). Tenth step research approach is modified into five steps, namely the preliminary study or needs assessment,Plan daily development activities,device prototype, test, validity, and reporting. In the present study carried out a preliminary study / need assessment and designing prototype learning development tools ready and eligible to practice another time.Research subject is a kindergarten teacher groups Jempiring Denpasar Bali. The research data in the form of information about the number of songs that are worthy and known children with a good and simple dances that can be used for the physical development of the child's motor activity were collected through literature on institutions and interviews with relevant parties. The collected data were analyzed using the techniques of data analysis is inductive in accordance with the type of research that is descriptive qualitative (Miles and Huberman, 1984). Results showed that a valid creation of a learning device in the form of (a) RKPH and (b) a simple media such modifications song lyric children ready to be tested in future studies.
\end{abstract}

Keywords: development, music and dance, physical motor

\section{INTRODUCTION}

Education is an important asset for the progress of a nation, therefore every citizen must follow education from early childhood education, elementary education, secondary education, to higher education. In a large Indonesian dictionary, education is defined as the process of changing the attitude and behavior of a person or group of people. Furthermore, education is a form of learning experience that takes place in the family, school, and community environment to develop optimal capabilities from birth to the end of life (Wiyani \& Barnawi, 2014).

In early childhood education the implementation of education focuses on the basic laying toward growth and development of 6 aspects: moral and religious development, language and communication, emotional sociology (attitude and emotion), intelligence / cognitive (thinking power, creativity), physical development (co-ordination of gross and fine motor), and the development of art according to the uniqueness and stages of development of the age group through which young children live.Early childhood education as the founder of basic skills for the preparation of children in facing the task of further development should be able to provide the stimulation that can develop all aspects of development which children have as a whole and the maximum.

These six aspects of development need to be precisely stimulated so that the child can grow and develop optimally. One aspect of development that needs to get stimulation and special attention is the aspect of the physical development of the child's motor. The development of physical motor has a very important role for the life of the child, either directly or indirectly. Physical development goes hand in hand with motor development. Directly, a child's physical development will determine the child's skills in moving. While indirectly, physical growth and development will affect the child's perspective on himself and the child's perspective on others.

Therefore, physical and motor development can not be separated because they support each other. Motor development includes the development of gross motor and smooth motor. Gross motor 
abilities, ie movements resulting from the ability to control big muscles, while smooth motor skills are limited movements of parts that include small muscles, especially movements in the fingers.

Bambang Sujiono (2015) in his book entitled Physical Development Method states that the first five years is the period of rapid development of child motor. Motor in question is all the movements that may be obtained from the whole body, while the motor development is from the elements of maturity and control of gestures. Motor development also increases the coordination of gestures involving much smaller muscles and nerves or details. Muscle and nerve groups that are later able to develop fine motor movement and gross, such as squeezing paper, tearing, writing, jumping, jumping, tiptoe, twisting, and so forth.

The child's fine motor skills can be stimulated through activities such as plagiarizing, folding paper, meronce, weaving, matching, scissoring, tearing, drawing, coloring, shaping and sewing. While the abilities and gross motor development of children can be stimulated through the activities of dancing, singing, also play.

Observations of researchers to several kindergartens in the area of Denpasar City showed relatively similar results. Giving stimulation to improve the physical motor development of children, especially gross motor is done in a very simple way without a clear purpose. If it can be concluded from the field observation, the learning / giving stimulus for the growth of his child motor movement is done only for the fulfillment of the target of the curriculum, regardless of the child's feasibility and needs for its development. The absence of adequate facilities, infrastructure, or learning media, and the lack of knowledge and creativity of teachers to create, modify and utilize various sources of learning are the main reasons for the low quality of motor development in early childhood.

Further exposed motor development of students who are observed in Garut jempiring Denpasar still not in accordance with expectations. The low motor development in children is also caused by several problems such as the learning of motor development conducted by the teacher has not been able to stimulate the participation of children to take an active role in the learning activities. This is because the learning is very monotonous. Choice of methods and media less stimulate children to want to perform motion with a motor target, especially gross motor. The use of learning methods that are monotonous and unattractive causes the child to become bored in following the learning in the classroom. Therefore, teachers are required to choose the methods and learning media used in the learning process, of course, methods and learning media used must be in accordance with the circumstances, needs and abilities of students.

Overcoming the existing problems, can be pursued with the development of the right learning device. In addition to the proper use of the method is certainly supported by interesting activities to develop the child's physical motor skills one with modification of music and dance.

In human life can not be separated from the art, especially music. It has long been recognized that there is power behind vibration, rhythm, and sound. There is a belief that music has the power to influence the soul and change the destiny of all human civilization (Tetti Rahmi, 2013). Organs of the body that is most often touched by music is the brain, both the left brain and right brain. Children who, during their growth and development, have a lot to do with music intensely show a higher academic ability than those who do not like music. Even in Gardner's multi-intelligent theory, one of the eight intelligences that every human being possesses is musical intelligence ... (Gardner, 2005).

In addition to music, the basic movement of dance is also very influential on the physical development of motor child. Dance in early childhood as well as on dance in general, formed of elements of movement and other elements. The difference is in the quality of the resulting motion and the expected function and purpose of the dance activity. In early childhood very simple dance movements tailored to the motor skills of children while dance movements are generally more varied and more complicated. Also in terms of function and purpose of dance in early childhood is clearly very different from dance in general. By dancing, the level of stress and freezing of the child's mind can subside and even disappear. With the right choice of songs and movements can stimulate the development of gross motor physical children, especially those associated with the biomotor components of agility, flexibility, strength, accuracy, This activity is very popular with children especially when using music and songs that are well known to children. A variety of beautiful motions can be done with a joyful.

Based on these descriptions, this research is carried out by focusing on the development of learning tools in the form of daily development plans (RKPH), methods and media of gross motor physical development (movements aimed at 
improving some biomotor components) with activities of dancing and dancing (Music and dance), which is formulated in the following research problems How is the development of learning device of music and dance modification to improve the physical development of motoric early child in cluster Jempiring Denpasar.

The age of toddlers, especially the early age for a child is a period of growth and development that when passed well then the child will reap great rewards for his life someday. These periods are the deciding period, about where they will be taken whether to be a mature human being capable of optimizing all his abilities or vice versa. Therefore, all kinds of abilities needed to live his life later prepared in this period even since the baby in the womb. Because of this period is often referred to as golden ages.

When a baby begins to grow in the mother's womb, at that very moment she starts to organize and build her body little by little from the formation of a very complicated brain through a network that connects to all the organs of the body to its completeness and physical perfection. By the time a baby is born into the world, he still continues to proceed even more complex. There are many things that children want to know about their new surroundings, as well as many expectations that parents rely on the birth of the baby into the world. One of the many expectations is that the child can grow and develop well, acquire the best knowledge and skills as a future capital in his life in society. To be able to achieve that expectation cannot be denied that the role of the teacher is the main.

For early childhood the teacher's role is absolute to awaken and stimulate the nerves of the child's ears to grow well. How do teachers provide stimulation that many ways and one of them that is with songs and games of musical instruments. It is intended to arouse children's interest in various types of music and also the dance passed down by our previous generation (Tetty Rachmi, 2013).

There is a belief that music has the power to influence the soul and change the destiny of all human civilization (Zoltan Kodaly, 2013). Throughout history humans have created music for all the great events of their civilization, whether it is a special event that occurs with each member of the community as well as for the wider interests.

As with any language or other discipline, each has media represented by notations or symbols that have meaning, so that people can understand the fields of science.Similarly with music. Music has a language that is represented by certain symbols so that the composer's works can be presented and played by another musician or next generation at different times and places.

An ideal song and notation for early childhood is a song that has a text or a poem that is able to stimulate the child to move, and able to provide stimulation of children to listen to it. According to Palmer (1996) there are several things that need to be considered when the teacher chooses a song for his / her students, ie activating the child involved in class activities, related to the interests of children, relating to the world of children, thick with rhythmic elements, and easily presented the other version of the song with Replaced poem. It was further mentioned that a good song for an early child is if the song has a child-friendly, rhythmic melody that draws the attention of the child, departing from the same rhythm of the song as the message and the rhythm of the song, the song's text using the repeated words, And the melodic sound region adjusts to the child's sound area (Tetti Rachmi, 2013)

There is an easy way for teachers to create new songs for educational purposes of their students that are by changing or replacing some text or lyric of a particular song or change and replace the entire text of a song that is very familiar to the child. Music and dance is a technique of playing while singing, this activity can train motor and creativity of children. Music and dance are very popular for children. According to his nature that early childhood is a child who in the age of playing and singing.

The world of children is a world of play. Children also always enjoy certain things he has ever seen especially the movement of objects is very interesting attention. The unconscious and spontaneous reaction in demonstrating the motion in accordance with what is seen and observed. The expressions of the child's motion are wise, quick, and describe the excitement. These body movements are the main mediums rather than the early childhood. These movements are formed from energy, space, and time.

There are two important aspects in dance, namely aspects of motion and aspect of rhythm. Both of these aspects have been known since early childhood as at the age of children half to one year. Limb movements such as hands and heads can usually be stimulated by sounds such as rhythmic clapping or simple sounds. This kind of event usually occurs in babies wherever they are. This often happens in an atmosphere of joy. 
In relation to the child's motor development, motor development is related to the development of the child's movement ability. Motion is a major element in motor development of children. Therefore, the development of the child's moric ability will be clearly visible through the various movements and games they can perform. If the child moves a lot, the more benefits a child can get when he is more skilled at mastering his motor movements. The child will also be more confident and independent because he has positive social skills.

The development of child motor is divided into two parts, namely the development of gross motor movement and fine motor movement. Gross motor movement is formed when the child begins to have coordination and balance almost like an adult. Gross motor movement is the ability that requires coordination of most parts of the child's body. Therefore, it usually requires power because it is done by the big muscles. The development of gross motor motion also requires coordination of certain muscle groups of children that can enable them to jump, jump, climb, run, ride a tricycle and stand on one leg. In fact, there are also children who can do the movement somersaults. In general, gross motor movements done children outside the classroom. To stimulate a child's gross motor, according to Hadith (2003), it can be done by training a child to jump, climb, squeeze, make a happy expression, sad, happy, running, on tiptoe, walking on one leg, also walking on the bridge.

In its development, gross motor develops earlier than fine motor. This can be seen when the child is able to use the leg muscles to walk before he can control hands and fingers to edit or meronce. If concluded gross motor skills, ie movement resulting from the ability to control the gross muscles, as well as fine motor skills, the limited movement of the parts covering the small muscles, especially in the fingers, for example is to write, Drawing, holding something (Hildayani, et al., 2008: 8.5).

According to Sujiono, et al. (2015) fine motor movement is a movement that involves only certain body parts and is performed by small muscles, such as the skill of using the fingers of the hand and the proper wrist movement. Therefore, this movement does not require much energy, but requires careful eye and hand coordination. Fine motor movements when kindergarten children are generally shown by the movement of children who have started to brush their teeth, combing hair, opening and closing zippers, wearing their own clothes and shoes, and feeding themselves using spoons and forks.

Based on the description and some opinions above, it can be drawn a conclusion that the development of child motor is closely related to the physical and intellectual conditions of children and progresses gradually but has a different developmental speed flow in each child. Motor development includes the development of fine motor and gross motor. Both motor movements are indispensable to children in the future.

In general, early childhood is very playful. Through play, they learn to move and play music. These activities develop their motor skills. Development of fine motor skills can be found in the game of musical instruments that use a lot of fingers, while the development of gross motor skills can be found and developed when children perform dancing activities and playing marching band. When child music also simultaneously develops another sensormotor sensitivity such as when a child plays 'Bentik' from bamboo, the child must coordinate between eye and hand. Look for blades to be struck using the sense of sight, and precise hitting movements on the desired blades with the skill of holding the stick and hitting it on the selected bar.

The experience of an expert who conducted an experiment by collecting two groups of early childhood to see that the habit of presenting the rhythm of music and songs was a positive effect on motor skills of children. One group for one year is given musical activity of singing and playing music singing to music, and while in second group is not given music activity. At the end of the year, he found that the scores for the development of motor perceptual of children in the first group were higher than in the second group. In the following years, other researchers confirmed the findings.

Through songs, games with songs like "Dragon Serpent" and "Train Up" tracks can stimulate the child to move actively with his friends and teachers. Through children's songs can harmonize the movement, increasing the way the body works in the end the process of motor development will be able to run well. This activity will greatly assist teachers in encouraging children who have difficulty in motor development.

\section{METHOD}

This research uses R\&D designs (Gall and Borg, 1989). That is caused by this research intend to developing learning media that aims to increase the development of motor physical early childhood. 
According to Borg and Gall (1989), there are 10 steps in implementation of R\&D designs namely: (1) Research and information collecting,(2) Planning, (3) Develop preliminary form of product, (4) Preliminary field-testing, (5) Main product revision,(6) Main field-testing, (7) Operational product revision, (8) Operational field-testing, (9) Final product revision, and (10) Dissemination and implementation.All ten steps that are described in this research practice are modified into five steps namely: (1) Collecting the information/needs analysis, (2) Developing prototype model in the form of learning device that aims to aspect of child motor, (3) expert validation, (4) testing in a class setting that is limited, and (5) revising until it becomes valid model.

The research stages are presented in the chart

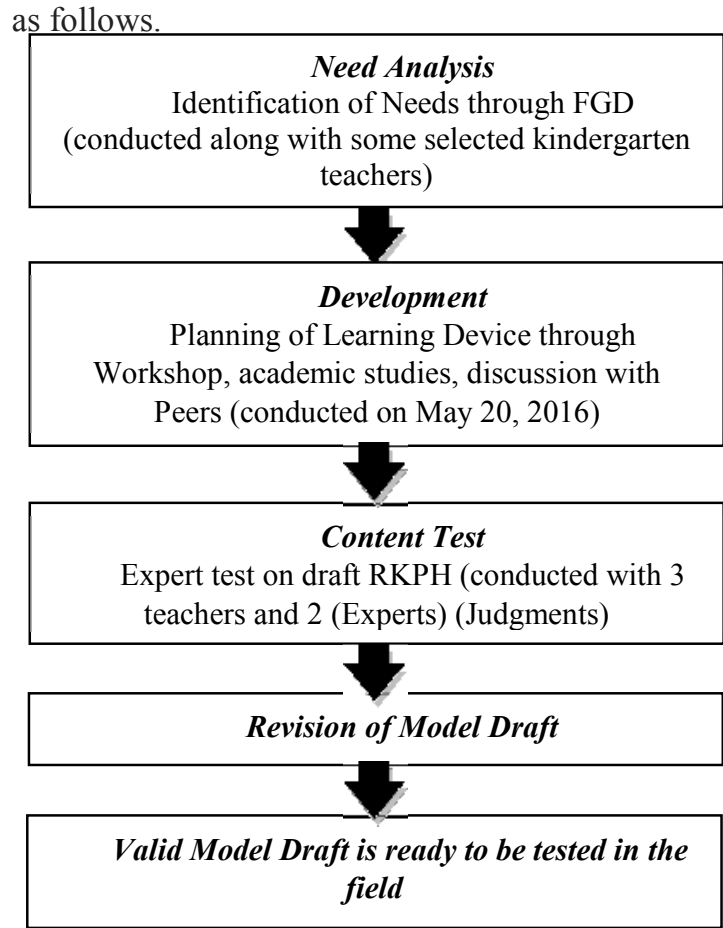

Figure 1. Stages of Research Implementation

This research was conducted in Gugus Jempiring Kindergarten in DenpasarCity (in some representative areas namely Kusuma Kindergarten Number 2, Harapan Bunda Kindergarten, and Tunas Daud Kindergarten) and involved a number of subjects appropriate with the needs of the research stages ( 3 principles, 3 kindergarten teachers, and 2 experts).

The data were collected by using observation method, document study, and questionnaire. The fully developed research chart with clear phases, the location of the research implementation, unusual data collection techniques needs to be explained, as well as the measurable analysis, outcomes, and performance indicators complement the research method. The instrument that was used in capturing this research data was self-researcher itself who was present in the field as a key instrument.

The collected that had been collected then analyzed descriptively by involving quantitative and qualitative methods. Quantitatively can be described the quality of learning devices that was produced; While qualitatively inferential can be done in depth about the symptoms that occur related to the quality of learning devices obtained based on observation, analysis, and inference that were conducted.

The final output that was produced from this research activity was learning apparatus of early childhood motor development in the form of RKPH with music and dance methods, and learning media in the form of $\mathrm{CD}$ examples of music and dance to improve motor development of early child.

\section{RESULT AND DISCUSSION}

Based on the analysis of teacher and expert responses to learning tools that was developed in the form of Daily Development Activity Plan contained in this report was obtained results as shown in the following table1.

Based on the table seems that from 3 early childhood education teachers who are selected as user validators, the average yield in percent for the ten components validated was $93.9 \%$. These results if included in a predetermined assessment scale indicates that the RKH qualification as a learning development tool that was developed is categorized as highly feasible and ready to be tested on the following research activities.

Table 2, Response 2 experts on Rencana Pengembangan Kegiatan Harian (RKPH) below.

Observing the results of the analyzes set forth in table 2 below, it seems that from two experts as validators, the average yield in percent for the ten components of the validated learning development tool was $96 \%$. Those results if included in a predetermined assessment scale indicates that had been determined showed the qualification of device in form of RKPH that was developed is categorized as highly feasible and ready to be tested in future research.

Finally, from the average results that indicated by the two validators, it can be concluded that the daily development tools that is produced to improve early childhood motor development are feasible and 
ready to be tested in the preschool children researched in the following year. Similarly, the results of responses analysis of motion and song that are developed to support the implementation of motor development is declared appropriate, feasible, and ready tested in the next try to see the impact of the implementation and its achievement namely development of early childhood motor.

Observing the results of research that had been exposed, the development of learning tools and the use of media motion and songs to improve the development of motor physics of children developed in this study is believed to be able to contribute very valuable in supporting development, especially the development and improvement of education quality in early childhood. Research products in the form of learning device tools include: $\mathrm{RKH}$, simple media motion and song, would be able to overcome the problem that until now less get the attention of kindergarten teachers. Described by Aussie (1996), playing included in it was a trajectory for children aside from being a powerful tool or learning medium for young children, was also a necessity for every child. For that it toke time and attention enough to provide opportunities to play for children, especially for children who were still in its infancy such as early childhood. When playing while chasing children could meet the needs of his motion. The need for this motion could not be fulfilled during school hours at school activities only by sitting indoors. Therefore, early childhood education teachers should be able to meet the needs of the students movement with various alternative motion games and songs that could be done children. According to (Pradana, 2012) playing not only giving positive influence to the growth of child's organs caused by active move. Playing and singing also served as a sublimation process which means an escape from excessive suppressed feelings toward positive things. Through child sublimation would lead to a more noble, more beautiful, and more creative.

The importance of constantly developing early child motorics through motion and song was not without reason. This is because moving for early childhood was a vehicle that was strategic enough to be done and developed both at school and at home. With the generation of learning tools for early and viable early childhood development programs this year was expected to be piloted and applied to next year's research activities. The device produced in this research year had at least helped teachers contribute to the formation of healthy humans physically and spiritually. Through the activity of physical motor development, children had the opportunity to learn to improve their knowledge, skills and attitudes, as well as learn to cooperate, to obey the rules, to appreciate time, to share and help, and also to train concentration or concentration on individual tasks that must be done.

On the other hand, a good and routinely measured physical motor development had a positive value, for example, a child becomes more mobile and thus avoids child obesity. Their socialization with others would be better because it was done together with joy.

Obstacles experienced in general was the limited field or space for kindergarten children in big cities, while many activities of motion and songs that required a vast arena. The development of a decent and valid learning development tool could also develop the abilities of biomotor components that were indispensable in the daily life of the students, such as (1) the power of explosive power (work) that could be done in one time or in one movement. Explosive power referred to the explosion power which was explosive consisting of two biomotoric components, namely the element of strength and the velocity element, (2) the constituent element, i.e. the body's ability to extend itself to an extent supported by the extent of movement in the joint, (3) agility, i.e. the ability to change body position or direction of body movements quickly while moving quickly, without loss of balance or awareness of orientation to the position of the body,(4) elements of reaction time is the time needed since stimulation began to be accepted by (senses) until muscle effectors react On the stimulus, (5) the element of coordination is to choose and decide an answer quickly and accurately to respond stimulation through the efferent nerve to a certain effector, (6) the element of balance is the body's ability to react to any changes in body position, so that the body is stable, and (7) the element of accuracy is the body's ability to control the free movement toward a target.

Based on these facts, it was not wrong and not exaggerated to say through the activities of moving and singing in schools many psychological functions and personality traits that could be implanted and developed in accordance with what is desired in community life (Oka Negara, 2011)

Types of dance that could be done by early childhood adjusted to the motor skills of early childhood. In early childhood dance lessons the aim was not to train children to be professional dancers but rather as a vehicle to help preparing children for 
creative, innovative, and high sensitivity, as expressed in general educational goals. Therefore, the type of dance in early childhood must serve as a medium of expression, communication media, as a medium of play, media talent development and creativity media. Characteristics of dance that could be performed by early childhood include: selected themes must be in accordance with the psychology of early childhood, such as the theme of the surrounding environment, human behavior, work activities, animal behavior, and behavior of characters in fairy stories and so on.

Motor development of children was closely linked to the physical and intellectual condition of the child and toke place gradually but had a different groove on the speed of development of each child. Basically, these developments evolved in line with the maturity of the child's nerves and muscles. Thus, any simple movement of any kind was the result of a complex interaction pattern of the various parts and systems in the body that is controlled by the brain. Thus, it was the brain that functioned as part of the nervous system that regulates and controlled all the physical and mental activity.

\section{CONCLUSIONS}

Based on the background to the discussion described earlier, the following conclusions can be drawn: First, in terms of legibility and clarity of exposure, early childhood development tools in the form of RKPH to develop early childhood motor skills are feasible, clear, and ready to be piloted on Kindergarten children are either limited or wider; Secondly, in terms of material adequacy and conformity with early childhood capabilities the devices developed have also been feasible, appropriate, and ready to be tested in kindergarten children either limited or broadly researched; And the three simple media in the form of motion and songs that have been modified created to support the smooth development of motor child is also located in the category of decent and ready to be tested.

\section{REFERENCES}

[1] Aswin Hadis, Fawsia. 2003. Perkembangan Anak dalam Perspektif Pendidikan Anak Usia Dini.Buletin PADU Vol 2. No 1. April 2003, ISSN 1693-1947.

[2] Borg, W.R. \& Gall, M.D. 1989.Educational Research. New York: LongmanAccessed on $10^{\text {th }}$ January 2015
[3] Gardner, H. (2005). Inteligencias múltiples. Paidós, 1-14. Retrieved from http://ict.edu.ar/renovacion/wp-

content/uploads/2012/02/Gardner_inteligencias .pdflnhttp://datateca.unad.edu.co/contenidos/40 $1509 / 2014-$

1/unidad_I/Gardner_inteligencias.pdf

[4] Harlock. Elizabeth B. 1978. Perkembangan anak.Jakarta: Erlangga.

[5] Hildayani, Rini dkk. 2008. Psikologi Perkembangan Anak. Jakarta: http://ejournal.undiksha.ac.id/index.$\mathrm{php} / \mathrm{JJPAUD} / \mathrm{article} / \mathrm{view} / 1001$.

[6] Kodaly, Zoltan. 2013. Pengaruh Musik pada Perkembangan Anak UsiaDini. Jakarta: Universitas Terbuka.

[7] Marheny, Retno. 2013. Upaya Meningkatkan Kemampuan Motorik Halus Anak melalui Kegiatan Finger Painting di Pos Paud Mekar Lestari Pokak Ceper Klaten Tahun Ajaran 2012/2013.Ejournal.Universitas

Muhamadiyah

Surakarta.Tersediahttp://Eprints.Ums.Ac.Id/23 685/13/NASKAH PUBLIKASI.Pdf.

[8] Pertiwi, Ida Yunita Aci. 2013. Peningkatan Keterampilan Motorik Halus melalui Kegiatan Finger Painting Anak Usia 5-6 Tahun di TK Ibnul Qoyyim Sleman.E-journal.Universitas Negeri Yogjakarta. Tersedia pada http://eprints.uny.ac.id/14681/1/Ida\%

Singaraja: Skripsi tidak diterbitkan.

[9] Pradana, H. Y. (2012). PEMBELAJARAN MUSIKAL UNTUK ANAK - ANAK. Undergraduate Thesis, UPN "VETERAN" YOGYAKARTA., (Game pembelajaran), 1-11. Retrieved from http://repository.upnyk.ac.id/id/eprint/3021

[10] Rachmi, Tetty.2013. Keterampilan Musik dan Tari. Jakarta: Universitas Terbuka

[11] Rachmi, Tetty. 2013. Kontribusi Musik pada Perkembangan Anak Usia Dini. Jakarta: Universitas Terbuka

[12] Risanti, Ni Made Nita. 2013. Penerapan Metode Pemberian Tugas Berbantuan Media Konkrit melalui Kegiatan Musik dan tariuntuk Meningkatkan Perkembangan Sosial Emosional".

[13] Sujiono, Bambang. dkk. 2005. Metode Pengembangan Fisik. Jakarta: UniversitasTerbuka

[14] Wiyani Ardy Novan dan Barnawi. 2014. Format PAUD. Jogjakarta:.Ar-Ruzz Media. 
Table 1. The 3 Teachers' Responses to the RencanaPengembanganKegiatanHarian (RPKH)

\begin{tabular}{|c|c|c|c|c|c|c|c|c|}
\hline \multirow[t]{2}{*}{ Number } & \multirow{2}{*}{$\begin{array}{l}\text { Components that are } \\
\text { assessed / Indicators } \\
(5 \mathrm{RKPH})\end{array}$} & \multicolumn{5}{|c|}{$\begin{array}{l}\text { Frequency of the subject who chooses } \\
\text { Alternative Answers }\end{array}$} & \multirow{2}{*}{$\begin{array}{l}\text { Amount in } \\
\text { Percent }\end{array}$} & \multirow[t]{2}{*}{ Qualification } \\
\hline & & 5 & 4 & 3 & 2 & 1 & & \\
\hline 1 & Theme & 10 & 5 & & & & $100 \%$ & SL \\
\hline 2 & $\begin{array}{l}\text { Formulation of Learning } \\
\text { Results Indicators }\end{array}$ & & 11 & 4 & & & $73 \%$ & $\mathrm{~L}$ \\
\hline 3 & $\begin{array}{l}\text { Choice of development } \\
\text { activities }\end{array}$ & & 12 & 3 & & & $80 \%$ & SL \\
\hline 4 & Tools and sources & 5 & 10 & & & & $100 \%$ & SL \\
\hline 5 & $\begin{array}{l}\text { Choice of variety of } \\
\text { development activities }\end{array}$ & 3 & 12 & & & & $100 \%$ & SL \\
\hline 6 & $\begin{array}{l}\text { Time allocation } \\
\text { Development activities }\end{array}$ & & 13 & 2 & & & $86 \%$ & SL \\
\hline 7 & Ways of organizing children & & 15 & & & & $100 \%$ & SL \\
\hline 8 & Type of evaluation & 15 & & & & & $100 \%$ & $\mathrm{SL}$ \\
\hline 9 & Language usage & 3 & 12 & & & & $100 \%$ & SL \\
\hline 10 & Cleanliness & 6 & 9 & & & & $100 \%$ & SL \\
\hline & Average Teacher Response & & & & & & $93.9 \%$ & \\
\hline
\end{tabular}

Table 2. Response 2 experts on Rencana Pengembangan Kegiatan Harian (RKPH)

\begin{tabular}{|c|c|c|c|c|c|c|c|c|}
\hline \multirow[t]{2}{*}{ Number } & \multirow[t]{2}{*}{$\begin{array}{l}\text { Components that are assessed } \\
\text { / Indicators } \\
\text { (5 RKPH) }\end{array}$} & \multicolumn{5}{|c|}{$\begin{array}{l}\text { Frequency of the subject who chooses } \\
\text { Alternative Answers }\end{array}$} & \multirow[t]{2}{*}{$\begin{array}{l}\text { Amount in } \\
\text { Percent }\end{array}$} & \multirow[t]{2}{*}{ Qualification } \\
\hline & & 5 & 4 & 3 & 2 & 1 & & \\
\hline 1 & Theme & 10 & & & & & $100 \%$ & SL \\
\hline 2 & $\begin{array}{l}\text { Formulation of Learning } \\
\text { Results Indicators }\end{array}$ & 3 & 7 & & & & $100 \%$ & $\mathrm{~L}$ \\
\hline 3 & $\begin{array}{l}\text { Choice of development } \\
\text { activities }\end{array}$ & & 8 & 2 & & & $80 \%$ & SL \\
\hline 4 & Tools and sources & 1 & 8 & 1 & & & $90 \%$ & SL \\
\hline 5 & $\begin{array}{l}\text { Choice of variety of } \\
\text { development activities }\end{array}$ & 4 & 5 & 1 & & & $90 \%$ & SL \\
\hline 6 & $\begin{array}{l}\text { Time allocation Development } \\
\text { activities }\end{array}$ & 8 & 2 & & & & $100 \%$ & SL \\
\hline 7 & Ways of organizing children & 7 & 3 & & & & $100 \%$ & SL \\
\hline 8 & Type of evaluation & 10 & & & & & $100 \%$ & SL \\
\hline 9 & Language usage & 3 & 7 & & & & $100 \%$ & SL \\
\hline \multirow[t]{2}{*}{10} & Cleanliness & 6 & 4 & & & & $100 \%$ & SL \\
\hline & Average Teacher Response & & 6 & 2 & & & $96 \%$ & \\
\hline
\end{tabular}

